\title{
Review of Sustainability of "Sustainable" Energy Use: Historical Evidence on the Relationship Between Economic Growth and Renewable Energy
}

\author{
Desalegn Jara Godibo, \\ Department Of Physics, Wolaita Sodo University
}

\begin{abstract}
This review considers economic growth in a renewable energy system. In this review tried to show that economies of the past survived, evolved and even grew within a renewable energy system. Indeed, the key observation is that, in particular locations, industries were operative and dependent on renewable energy sources for centuries and even millennia. The growth in demands does clearly put pressure on resources. For instance, the expansion of the European and Far East Asian population and economy between 900 and 1350 and 1400 and 1800 led to a growth in demand for energy resources. We investigated the 'sustainability' of the use of this 'sustainable' energy that is, how the renewable resource was used over very long periods. This involves considering the availability of resources, the rate of use, the existence of energy crises and the various governments' attempts to manage demand and supply. In many localities, wood fuel supplies were able to meet the growing demand. This was, in cases considered, the result of government intervention and the promotion of better resource management. Often, they were coupled with efforts to reduce demand and improve efficiency of consumption. Based on the historical evidence, balancing demand and supply was crucial to achieving growth within a renewable energy system. In many circumstances, trade was the solution, importing the necessary resources. Where local energy shortages were a problem, the main cause was due to the high cost of transporting resources, rather than an overall energy crisis.

In addition to these, a Future Economy Driven by Renewable Energy, Sustainable Energy Technologies in developing counters, Renewable Energy Consumption and Economic Growth have all been included and discussed.
\end{abstract}

Keywords: Sustainability, Sustainable energy, economic growth and renewable Energy DOI: $10.7176 /$ JETP/9-1-02

\subsection{Introduction}

Throughout history, energy resources have played an important role in influencing the rate of economic growth and development. It has been seen as a boost to long term growth when new energy sources and technologies were deployed and created abundance (Rosenberg 1998). They have also been responsible for slowing down economies in times of perceived scarcity (Nordhaus 1980). Given the interest in a transition to a low carbon economy, it is appropriate to ask about the role energy might play in this new context. At present, one can only speculate about the relationship between economic growth and development and low carbon energy resources. A transition to low carbon energy sources may provide a boost to the economy. Alternatively, an increasing dependence on renewable energy will imply different levels of resource availability and may create new limits on economic growth or meeting the economy's energy needs through renewable resources may impose substantially higher costs. Many of the models of long run energy use have presented a cheap, non-renewable energy and an expensive renewable energy as the backstop technology (Cipolla 1962). A transition to the more expensive renewable energy source means that firms would have to charge more for their products and customers budgets would not stretch as far. Thus, it would effectively act as a break upon economic growth. These models present the transition to a backstop technology as the result of a severe depletion of the nonrenewable energy source, leading to high prices and a need to find substitutes. Empirical studies and, recently, theoretical models question whether the non-renewable resource will face long run scarcity issues and rising prices(Tahvonen and Salo 2001).

This review imply that if a transition to renewable energy sources were to take place, it would not be the result of dwindling fossil fuel reserves, but the result of either a preference for renewable energy or that it became cheaper than fossil fuels. Based on historical experiences, Fouquet (2010b) argues that, although preferences are important, a transition to low carbon energy sources is unlikely without renewable energy providing energy services more cheaply than fossil fuels. This implies that a complete transition will only occur if the combined output of renewable energy and its associated technology is cheap. Thus, the transition to renewable energy sources is unlikely to impose higher prices at least, not initially. Yet, perhaps more in the long term, after the transition and the economy becomes dependent on renewable energy sources, it may face resource limits. Over the last three hundred years, modern economies have managed to grow spectacularly and have had an almost insatiable demand for energy resources (Fouquet 2008). So, even though supplies of renewable energy 
resources are potentially very large (compared with the size of the global economy), limits may indeed eventually be faced

Traditional models of long run energy use do not address the situation once the backstop technology is the dominant energy source that was not their purpose. While a transition to renewable resources is certainly decades away, at the earliest, there is now a clear demand for a better understanding of the relationship between long run economic growth and renewable energy use. In order to begin our understanding of the relationship, this review gathers some evidence on how past economies have managed within the confines of renewable energy system. Given space limitations, this review only seeks to present snapshots about a variety of different cases focusing on sustainable energy (wood fuel). These cases relate to the Roman Empire, Early Modern Europe and the Far East. We investigate the 'sustainability' of the use of this 'sustainable' energy that is, how the renewable resource was used over very long periods. This involves considering the availability of resources, the rate of use, the existence of energy crises and the various governments' attempts to manage demand and supply.

\subsection{Wood fuel Consumption during the Roman Empire}

Roman daily life was highly dependent on wood fuels. In addition to the consumption for cooking, hot baths, preparation of lime for construction and cremations of bodies were major users of fuel wood. Heating may have consumed as much as 90 percent of the timber used. Estimates suggest that, at its peak, with 1.5 million inhabitants, Rome would have consumed 2.25 million $\mathrm{m}^{3}$ (equivalent to 0.7 million tons of oil) and required more than $30 \mathrm{~km}^{2}$ of forest per year.

There is evidence that forests were coppiced or felled in rotation to be able to meet the demands of Roman energy requirements. And yet, inevitably, Rome's success and expansion imposed increasing pressures on forests, and the trade in wood spread ever further by the third century, the largest beams were shipped to the city from the Black Sea. Although the cost of cooking, bathing, building and cremating (until the practice was abandoned with Christianity, possibly encouraged by the price of fuel wood) must have increased, no claims of a Roman energy crisis exist.

The Empire also required large amounts of fuel wood to meet its demands for metal smelting. For instance, produced an estimated 500,000 tons of 4 copper, needing 2.2 million tons of charcoal (equivalent to 1.6 million tons of oil) from 36.1 million tons of wood, over a period of 500 years. This would have needed a forest of 1,875 $\mathrm{km}^{2}$ if it had been stripped of its trees. However, given that the annual consumption was relatively modest by modern consumption, land requirements could have been closer to 10 to $15 \mathrm{~km}^{2}$ if properly coppiced.

In classical times, many industrial sites dependent on charcoal managed to produce for hundreds and even thousands of years. Examples currently in Greece, Cyprus, Italy and Spain show that very large total quantities of silver, copper or bronze (fusion of copper and tin) were produced over long periods of time. For instance, copper smelting in Cyprus left 4 million tons of slag residues. This equates to 200,000 tons of copper, requiring 60 million tons of charcoal (equivalent to 43 million tons of oil) from 960 million tons of wood on roughly 60,000 square kilometer of forest. While Cyprus did suffer from deforestation, this was caused more from agricultural expansion than from industrial activities. And, they managed to produce copper for 3,000 years. Such large quantities of production over a very long period could only have been achieved if the use of wood for fuel had been managed in a relatively sustainable way. Thus, there is clear evidence that already in Classical times, energy requirements were often met in a sustainable manner. Modest growth could be met by managing a slightly larger area provided the source was easily accessible by land or by water.

\subsection{Early Modern European Energy Concerns}

The trend for much of human history has been of encroachment on woodlands. Although in specific cases, the growing use of wood for energy and timber was responsible, deforestation has been mostly due to agricultural expansion. Nevertheless, it implies a declining stock of resources for meeting wood fuel needs and an increasing distance between the source and many of the users. Between 1700 and 1850, temperate forest covers across the world declined substantially by 1.8 million square kilometer $\left(\mathrm{km}^{2}\right)$. In Europe, $250,000 \mathrm{~km}^{2}$ disappeared; in Russia, 710,000 km² in North America, 450,000 km²; and in China 390,000 km². Between 1850 and 1920, the rate slowed a little 1.29 million $\mathrm{km}^{2}$ disappearing. Russia lost $800,000 \mathrm{~km}^{2}$, North America $270,000 \mathrm{~km}^{2}$ and China $170,000 \mathrm{~km}^{2}$. Over that period, Europe only lost $50,000 \mathrm{~km}^{2}$, but this reflects more than anything a lack of forests to clear.

The trend in real energy prices over four hundred years of major economic growth is also revealing. For a number of cities across Europe, there was no evidence of an energy crisis and only a few instances of rising real energy prices between 1400 and 1800. Otherwise, the trends in real energy prices were stable or declining. There were wood fuel shortages, but they tended to be local problems, rather than national ones affecting the whole economy. Much of the problem was associated with distribution networks. And, most likely, shortages hit different localities at different times. Overall, between the early fifteenth and nineteenth centuries, the European economy managed to grow successfully and with little constraints while being mostly dependent on wood fuel 
for heating (Allen 2003).

The main commonality amongst all economies was that once agricultural production increased or efficiency improved population grew, putting pressure on wood fuel resources, both because of the changing land-use from forest to agriculture and the rising demand for wood products. Thus, consistently, economic growth eventually expanded to reach its resource limits. Faced with greater constraints, the reaction was economic contraction, stagnation or even decline, better management of forest resources or a switch to another fuel. The next section considers government policies to balance the demand and supply of this renewable energy.

\subsection{Forest Management in Germany}

The multitude of local German economies benefitted from large forests close to rivers. Wood fuel provided their main source of heating for households and industries for centuries, with episodic tensions and adaptation. Evidence suggests that consumers were reluctant to switch reflecting preferences for wood fuel and perhaps insufficient price differential to make substitution attractive and overcome the negative aspects of coal burning. When tensions did arise, wood fuel supply adapted to rising demands, either by felling more local trees or importing them along the river networks. In many cases, when economic growth led to pressures on resources, governments in German states did tend to intervene to assist the markets. For example, in Northern Germany, salt production depended on large quantities of wood to evaporate seawater. The industry managed to expand substantially (more than quadrupling) from the beginning of the fourteenth to the end of the sixteenth century without suffering from higher energy costs or fuel shortages. It did depend partially on importing fuel wood, and transport networks were crucial. In fact, the promotion of road building and development of navigable rivers were promoted for the purpose of supplying the region. And, this industry's eventual decline was in no way a result of energy restrictions.

The consensus about wood fuel shortages in Germany was that they were localized problems more associated with distribution of resources rather than a generalized lack of energy resources. The main problem was the lack of satisfactory transport routes to distribute. In the seventeenth and eighteenth centuries, this problem was alleviated in some regions by the expansion of rafting of timber and fuel wood to wooded uplands that had previously been undervalued. Another cause of shortages was the political boundaries. Many of the German states believed in energy self-sufficiency and in preserving resources for domestic use (and not exporting wood). So, in some cases, industries needed to carry wood long distances (up to $30 \mathrm{~km}$ ) within political boundaries when nearby sources existed but were outside the state limits (Wagner2001). German energy and wood fuel consumption until the nineteenth century was dominated by household needs for cooking and heating. Crude estimates indicate that wood fuel consumption was around 11 million $\mathrm{m}^{3}$ (equivalent to 5.5 million tons of oil) in 1500 and about 20 million $\mathrm{m}^{3}(9.8 \mathrm{mtoe})$ in the seventeenth and early eighteenth century. In comparison, around 1600 , iron production use would have been 1.5 million $\mathrm{m}^{3}$ (about 0.8 million tons of oil equivalent) and, by 1700 , silver, lead and salt production would have required less than 47 million $\mathrm{m}^{3}$ of wood. Industrial activity grew substantially in the second half of the eighteenth century, and iron production would have needed about 10 million $\mathrm{m}^{3}$ by 1800 . This indicates that general forest management policies were driven by a need to meet household needs. Nevertheless, many of the early German states responsible for introducing policies were reflecting the repercussions of concentrated demands for local industries.

Forest management in Germany began in the late medieval and early modern period. In 1368, pines were replanted in the municipal forests of Nurnberg. It initiated a series of policies of managing woodlands across German states and urban centers, especially between 1470 and 1550. This trend reflected in part a growing awareness of the need for a security of energy supply (either because of the welfare implications to the population or because of the legal tensions that developed over scarce resources) and for the management of stable fiscal revenue by avoiding volatile prices associated with the changing scarcity of resources.

On communal land, households had been granted rights by local authorities to extract wood. However, over time, the rate of extraction was increasingly specified as a means avoiding a tragedy of the commons. This was generally seen as an amount suitable to meet 'subsistence' needs creating problems for families who sought to produce goods for markets. In noble forests, peasants were generally also allowed to collect deadwood and cut small pieces, and, similarly, this practice became increasing controlled by officials.

Until the nineteenth century, woodland management was based on practices developed in the fifteenth century, and was not particularly innovative. It focused on felling trees by area, in relatively short succession, coppicing, and protecting (by, for instance, banning grazing around saplings) and promoting rapid regret. Although their control and power grew, forest officials' role was to assess the stocks and parry poaching.

When faced with demand pressures on resources, policies generally sought to minimize resource use, by encouraging fuel efficiency, rather than increasing supply, such as reafforestation and trying new tree species. This reflected the more immediate returns from improving fuel efficiency (especially to industries) than investing in programs to increase supply.

Institutional structure played an important role in the successful balancing of supply and demand. For 
instance, from the fifteenth century, regulations in Siegerland in Germany defined the nature and the rate of smelting and forging activities (including the number of working days), and banned the exports of iron ore, raw iron or charcoal. Despite being an important mining, smelting and forging region, and needing to important some charcoal, it appears that its dependency on renewable energy supplies did not limit economic activities until the nineteenth century.

German state governments also promoted a switch to coal, which was reluctantly adopted in the nineteenth century, when industrial demands did severely outstrip supplies. By then, growing concerns of losing lumber led to scientifically managed forests and government policies. Also, although the concept was vague and differed for each state, there was a general view that, in addition to the need to meet on going demands, resources should be maintained for future generations.

Before the nineteenth century, there were, no doubt, plenty of examples of areas where growth did lead to energy restrictions. Yet, in early modern Germany the existence and dependence on large wood reserves led to relatively successful policies of managing energy supplies and demand. This more involved energy policy no doubt reduced the tensions, but ironically delayed the transition to fossil fuels and the potential for greater economic growth.

\subsection{The Japanese Experience}

The early modern Japanese economy followed a similar course. It depended heavily on wood fuel for heating purposes. Facing the risk of shortages resulting from economic growth, local policies aimed at reducing consumption, improving efficiency, increasing supply and attempting a switch to coal. Like Germany, before the nineteenth century, coal substitution was the least successful of these policies. Its experience showed that, through regulation, governments could help boost renewable energy supplies, and balance it with demand.

During the sixteenth century, large-scale military conflict had used large quantities of timber. From the seventeenth century onwards, the country was at peace and population rose. Along with the encroachment of agriculture onto once wooded land, demand for timber for construction, shipbuilding and fuel led to severe deforestation. Soil erosion, floods, landslides, and barren lands were common occurrences in the seventeenth and eighteenth century.

In the second-half of the seventeenth century, feudal lords, who owned most of the forests, began efforts to reduce deforestation. The first policy was to ban wood removal from except with direct authorization from the feudal lord. Other measures included seedling protection, selective cutting and more patrols. These measures reduced production substantially, but also feudal lord revenue. Swiftly, production increased again to make back the losses and deforestation resumed.

In Japan, at the end of the seventeenth century, the rising price of wood fuel drove a few industrial activities, such as for salt and sugar, to start shifting towards coal use, where the fuel could be found and extracted easily. But, in this densely populated country, the external costs of coal production and consumption were felt and created conflicts. Mining generated considerable pollution in nearby rivers, and coal burning emitted noxious fumes and sticky residue. Given the highly organized nature of society, protests, litigation, compensation and regulation followed. Eventually, in the 1780 s, mines were closed due to their damaging effects on society and the environment and wood burning was encouraged. But, inevitably, and despite more complaints, the high price of wood fuel forced growing industries in the nineteenth century to use coal.

Before this transition, however, in the eighteenth century, efforts to halt deforestation resumed and were more successful. Wood use was rationed, specifying the amount of wood that could be consumed according to social status. Timber for construction was used more sparingly. More efficient stoves were promoted for the use in homes. And, at the end of the century, an active policy of planting new trees was introduced. Along with these new measures came a scientific approach to forest management. The story of Japanese forest management and broader energy policies has often been told as a story of sustainable management, but it took nearly two centuries of deforestation and attempts to achieve a growth in wooded lands.

\subsection{A Future Economy Driven by Renewable Energy}

The previous sections have presented histories of economies dependent on renewable energy. Being able to sustain growth depended on sound management of demand, supply and trade of renewable energy (wood fuel). Where governments failed to develop appropriate policies, growth and development was limited. Inevitably, the vast demands of full industrialization, coupled with inefficient energy technologies and primitive transport networks, implied that a transition to fossil fuels was critical for higher levels of economic growth and development, as seen during the nineteenth century in Germany and even Japan. At the beginning of the nineteenth century, 95 percent of global primary energy use came from renewable resources. By the beginning of the twentieth century, it fell to 38 percent. And, at the beginning of this century, it was down to 16 percent. Clearly, for many years still, the proportion of renewable energy in primary energy consumed at a global level will continue to decline, as the quantity of fossil fuels used increases (especially from contributions in 
developing economies) more than those of renewable.

Nevertheless, the tide may be changing. In a number of industrialized countries the proportion of renewable is rising. Indeed, as propose in their model, it is possible that, in the process of economic development, an agrarian economy uses renewable energy resources; moves to fossil fuels for a phase associated with industrialization and, then, reaching a higher level of technological and economic capability, returns to renewable energy sources.

The important drivers for energy transitions of the past were the opportunity to produce cheaper and better energy services. They may well be the drivers for a transition to low carbon energy sources. Internalization processes, such as carbon taxes or tradable permit schemes, can improve their competitiveness. But, it is likely that, for a transition to occur, low carbon energy sources and technologies will have to provide cheaper energy services.

If renewable manage to out-compete fossil fuels, then economies (industrialized or developing ones) will, in time, become dependent on these low carbon sources. Fossil fuels may, in the future, be seen as the 'necessary evil' that is, a cheap and dirty energy source that allowed economies of the past to reach a higher level of economic well-being. This fits with the concepts underlying the Environmental Kuznets Curve that environmental pollution needs to get worse before getting better. But, will individual economies and the global economy be able to grow in the very long run within the confines of a renewable energy system? Although huge uncertainties about the future prevail, an exercise that considers the currently estimated global energy resources can help indicate the distance between the current global economy and notional limits.

For instance, one estimate of oil reserves of all types (nearly 2 million mtoe) suggests that they are currently 12 times the amount of oil that has been consumed in the industry's 160 year history (157,000 mtoe) or 486 times the 2009 global consumption of petroleum (Farrell and Brandt 2006). In 2009, the current global primary energy consumption was a little over 11,000 mtoe and the global primary energy consumption, including biomass, is likely to be around 12,000 mtoe. One estimate of global fossil fuel reserves is close to 30 million mtoe. This is nearly 2,500 times the current annual global primary energy consumption. Unconventional 12 natural gas reserves are especially large roughly $80 \%$ of the total. But, as indicated above, even for oil reserves, the estimate is more than 450 times the current annual global oil consumption.

Thus, even allowing for economic and population growth, fossil fuels are abundant. Thus, dwindling fossil fuel reserves is unlikely for a very long time. Without full carbon capture, atmospheric limits (to assimilate greenhouse gases) will have been reached far before resource limits. An estimate of the technical potential for global renewable energy resources is over 180,000 mtoe. Two-thirds of this potential would be generated by geothermal sources; one-fifth from solar; one-twelfth from wind; one-twentieth from biomass. So, for example, the potential for wind energy is estimated to be $25 \%$ greater than the current global energy consumption. And, the total technical limit is 15 times the global economy's primary energy requirements just as a reference, the current global primary energy consumption is 15 times its level in 1900. Thus, it took around one hundred years to grow 15 -fold. Although, we may not expect similar growth rates or a full dependence on renewable energy sources at the beginning of twenty-second century, these renewable energy limits could be threatened in the twenty-second century.

This is not an exercise in showing that a transition to renewable energy sources is dangerous for the economy. After all, an estimate of the 'theoretical' limits of renewable energy resources was nearly 3.5 billion mtoe almost 300,000 times the current global primary energy requirement. These are potentially meaningless numbers, given the developments in energy technology we can expect over the next hundred years and more. Presumably, the limit is somewhere between 15 and 300,000 times current consumption. However, they do help to think about magnitudes. Some have argued that increases in resource discoveries and improvements in energy technology were an important source of economic growth in the past. The ability to exploit new energy reserves, such as Colonel Drake's oil discovery in Pennsylvania or the extraction of oil in the Middle East, were also boosts to economic growth.

It is possible that within the limits of a renewable energy system, there will be less potential for new discoveries to be made.

Some might argue that the location of these resources is known with greater certainty for most renewable than for fossil fuels. So, the potential for great new discoveries in the future is less likely. Effectively, the limits are known and the global economy will work its way towards them. However, it is clear that renewable energy technologies of the future will be heavily dependent on research and development to improve their ability to harness natural forces. Technological developments will enable the economy to increase the limits of commercially viable renewable energy resources (from 15 times current global primary energy requirements towards 300,000 times). Thus, a crucial process within the renewable energy system will be the quality of signals that indicate existing limits are being reached and technological improvements will be needed to avoid serious constraints on economic growth. Probably more important than the limits will be the governments' energy policies. 
Historically, sound policies towards energy demand, supply and trade were critical to extending the ability to use renewable. This may offend certain ideologies but, based on historical evidence, a return to renewable energy sources would be more successful if properly managed, instead of laissez-faire approach. Policies will probably need to address short and long term demand, supply and distribution issues. Yet, it is possible and hopeful (from an economist's perspective), that the policies will be 'light-handed' and using incentives, rather than heavy regulation.

\subsection{Sustainable Energy Technologies}

The different energy supply technologies that will likely play a role in a carbon constrained future have been extensively reviewed elsewhere. The usual list includes renewable energy technologies (e.g., wind, solar and biomass), nuclear technology and advanced fossil-fuel systems with carbon capture and sequestration. Natural gas systems are widely viewed as a crucial 'bridge' technology. In addition, energy efficiency is often cited as a critically important and an often lower-cost complement to improvements on the supply side.

In principle, the same supply- and demand-side options are available to all countries. Nevertheless, some options especially technologies that are in the very early stages of commercialization, or that requires very large, upfront capital investments or substantial outside expertise to operate is likely to face additional deployment hurdles in developing countries.

A number of renewable energy technologies have improved to the point where they can now provide electricity at lower cost than other supply options wherever grid extension is prohibitively expensive or uneconomic. There are six broad categories of renewable energy technologies- biomass, wind, solar, hydro, geothermal and marine. They can be tapped using a variety of conversion technologies or processes to produce a range of energy services, including electricity, heat (or cooling), fuels, mechanical power and illumination. The competitiveness of different renewable technologies in different settings depends on their cost and performance, as well as on the local cost and availability of fossil-based energy. Both factors still vary widely and depend strongly on local conditions.

For example, many renewable energy sources are inherently intermittent. Thus their integration into a unified electricity grid can pose challenges, especially on a large scale, and may make them less competitive with conventional generating systems. In dispersed, off-grid applications, by contrast, intermittency may pose less of a problem and renewable technologies may be more cost-effective than the next available conventional option. In addition, their modularity that is, the fact that many renewable energy technologies can be deployed in relatively small unit increments- may be advantageous from a cost and risk standpoint in many developing countries.

In general, costs for most forms of renewable energy have declined substantially in recent decades. In the early 1990s, only hydropower was competitive with conventional power plants for on-grid applications. Since then, expanding markets and experience-driven cost reductions have made wind and geothermal power competitive or nearly competitive with other, conventional sources. Solar photovoltaic technology remains more expensive but can compete in some off-grid niche market applications. These comparisons are, of course, based on narrow criteria of strict cash flow and ignore other advantages, such as environmental benefits, that renewable technologies can confer (G8 RETF, 2001).

Tablel shows current and projected future costs for selected renewable technologies. The figures are somewhat dated, but they indicate how much further costs might be expected to fall with additional experience, larger-scale deployment and continued technology improvement. Prospects for continued cost reductions are promising given recent rapid growth in renewable energy markets. Over the past several years, the global rate of increase in installed wind and photovoltaic capacity has averaged as much as 30 percent per year, making these some of the most rapidly expanding energy technology markets in the world. 
Table 1: Current and Projected Future Costs of Renewable Energy Technologies:

\begin{tabular}{|l|c|c|c|c|c|}
\hline \multicolumn{2}{|c|}{ Current energy costs } & \multicolumn{2}{c|}{ Potential future energy costs } \\
\hline Sources & Units & Low & High & Low & High \\
\hline Bio-mass/Ethanol & $\$ / G J$ & 8 & 25 & 6 & 10 \\
\hline Bio-diesel & $\$ / G J$ & 15 & 25 & 10 & 15 \\
\hline Geothermal-Heat & $\mathrm{c} / \mathrm{kWh}$ & 0.5 & 5 & 0.5 & 5 \\
\hline Biomass-Heat & $\mathrm{c} / \mathrm{kWh}$ & 1 & 6 & 1 & 5 \\
\hline Geothermal-Electricity & $\mathrm{c} / \mathrm{kWh}$ & 2 & 10 & 1 & 8 \\
\hline Large Hydro & $\mathrm{c} / \mathrm{kWh}$ & 2 & 10 & 2 & 10 \\
\hline Small hydro & $\mathrm{c} / \mathrm{kWh}$ & 2 & 12 & 2 & 10 \\
\hline Solar low Temperature Heat & $\mathrm{c} / \mathrm{kWh}$ & 2 & 25 & 2 & 10 \\
\hline Wind Electricity & $\mathrm{c} / \mathrm{kWh}$ & 4 & 8 & 3 & 10 \\
\hline Biomass Electricity & $\mathrm{c} / \mathrm{kWh}$ & 3 & 12 & 4 & 10 \\
\hline Marin- current & $\mathrm{c} / \mathrm{kWh}$ & 10 & 25 & 4 & 20 \\
\hline Solar Thermal Electricity & $\mathrm{c} / \mathrm{kWh}$ & 12 & 34 & 4 & 2 \\
\hline Marine Wave & $\mathrm{c} / \mathrm{kWh}$ & 10 & 30 & 5 & 20 \\
\hline Solar PW Electricity & $\mathrm{c} / \mathrm{kWh}$ & 25 & 160 & 5 & 10 \\
\hline Marin -ocean thermal & $\mathrm{c} / \mathrm{kWh}$ & 15 & 40 & 15 & \\
\hline Marin-tidal & $\mathrm{c} / \mathrm{kWh}$ & 8 & & & \\
\hline Source: & & & & & 10 \\
\hline
\end{tabular}

Source: (adapted from UNDP, 2004).

Expectations of declining costs with greater field experience and larger scale deployment are not unique to renewable energy technologies. They would apply as well to other relatively new, low-carbon technology options (such as carbon capture and sequestration).

All renewable energy sources can be converted to electricity (in principle, energy can always be converted from one form to another). In actual practice, however, there will be some routes that will be preferred due to cost-effectiveness. Table 2 suggests some specific near-, medium-, and long term options for supplying basic energy needs in rural areas using low-carbon technologies. The mix of options likely to be optimal in different settings will depend on cost, scale, location, timing and availability of local resources and expertise and a host of other factors. In general, a greater diversity of supply options will help to reduce exposure to resource and technology risks. On the other hand, there are also trade-offs to be considered some standardization can help to reduce deployment costs and make it easier to develop the local expertise needed to operate and maintain new technologies and systems.

Table 2: Technological Options for Rural Energy

\begin{tabular}{|c|c|c|c|c|}
\hline $\begin{array}{l}\text { Energy } \\
\text { source/service } \\
\end{array}$ & $\begin{array}{l}\text { Present } \\
\text { options }\end{array}$ & Near term options & $\begin{array}{ll}\begin{array}{l}\text { Medium } \\
\text { options }\end{array} & \text { term } \\
\end{array}$ & Long term options \\
\hline Electricity & $\begin{array}{l}\text { Gird based } \\
\text { or no } \\
\text { Electricity }\end{array}$ & $\begin{array}{l}\begin{array}{l}\text { Natural gas } \\
\text { cycles } \\
\text {,biomass } \\
\text { coupled to } \\
\text { combustion internal }\end{array} \\
\text { wind, photovoltaic, small } \\
\text { hydro for remote } \\
\text { application }\end{array}$ & $\begin{array}{l}\text { Biomass gasifiers } \\
\text { coupled to micro- } \\
\text { turbines; mini girds } \\
\text { with combination of } \\
\text { photovoltaic, wind, } \\
\text { small hydro batteries }\end{array}$ & $\begin{array}{l}\text { Gird-connected } \\
\text { photovoltaic \& solar } \\
\text { thermal ,biomass } \\
\text { gasifiers coupled to fuel } \\
\text { cells and fuel } \\
\text { cell/turbine hybrids }\end{array}$ \\
\hline Fuel & $\begin{array}{l}\text { Wood, charc } \\
\text { oal, Crop } \\
\text { residues, } \\
\text { animal dung }\end{array}$ & $\begin{array}{l}\text { Natural gas, } \\
\text { producer gas, liquid } \\
\text { petroleum gas }\end{array}$ & $\begin{array}{l}\text { Syngas, dimethyl, } \\
\text { ether }\end{array}$ & $\begin{array}{l}\text { Dimethyl ether from } \\
\text { biomass with electricity } \\
\text { as a co-product }\end{array}$ \\
\hline Cogeneration & - & $\begin{array}{l}\text { Internal combustion } \\
\text { engines, turbines }\end{array}$ & $\begin{array}{l}\text { Micron-turbines with } \\
\text { integrated combine } \\
\text { cycles }\end{array}$ & $\begin{array}{l}\text { Fuel cells, fuel cell/ } \\
\text { turbine hybrids }\end{array}$ \\
\hline Cooking & Woodstoves & $\begin{array}{l}\text { Improved woodstoves, } \\
\text { liquid petroleum gas, } \\
\text { biogas }\end{array}$ & $\begin{array}{l}\text { Natural gas, producer } \\
\text { gas, dimethyl ether }\end{array}$ & $\begin{array}{l}\text { Electric stoves, catalytic } \\
\text { burners }\end{array}$ \\
\hline Lighting & $\begin{array}{l}\text { Oil and } \\
\text { Kerosene } \\
\text { lamps }\end{array}$ & Electric lights & $\begin{array}{l}\text { Fluorescence and } \\
\text { Compact Fluorescent } \\
\text { lamps }\end{array}$ & $\begin{array}{l}\text { Improved fluorescent } \\
\text { lamps, Compact } \\
\text { fluorescent lamps }\end{array}$ \\
\hline
\end{tabular}




\begin{tabular}{|c|c|c|c|c|}
\hline $\begin{array}{l}\text { Energy } \\
\text { source/service }\end{array}$ & $\begin{array}{l}\text { Present } \\
\text { options }\end{array}$ & Near term options & $\begin{array}{ll}\text { Medium } & \text { term } \\
\text { options }\end{array}$ & Long term options \\
\hline Motive power & $\begin{array}{l}\text { Human and } \\
\text { animal } \\
\text { power }\end{array}$ & $\begin{array}{l}\text { IC engines, electric } \\
\text { motors }\end{array}$ & $\begin{array}{lr}\begin{array}{l}\text { Bio-fueled } \\
\text { movers, } \\
\text { motors }\end{array} & \text { prime } \\
\end{array}$ & Fuel cells \\
\hline Process heat & $\begin{array}{l}\text { Wood, } \\
\text { biomass }\end{array}$ & $\begin{array}{l}\text { Electric furnaces, } \\
\text { cogeneration, producer } \\
\text { gas, Natural gas/ solar } \\
\text { thermal furnaces }\end{array}$ & $\begin{array}{l}\text { Induction furnaces, } \\
\text { biomass/ solar } \\
\text { thermal furnaces }\end{array}$ & $\begin{array}{l}\text { Solar thermal furnaces } \\
\text { with heat storage }\end{array}$ \\
\hline
\end{tabular}

Source: (Adapted from, UNDP. 2000)

Along with the need to extend basic electricity services to rural areas, many developing countries face rising demand for grid connected power to meet industrial and manufacturing energy needs and to provide electricity in fast-growing urban areas. In countries with access to substantial coal supplies, conventional coal fired steam electric power plants are often the cheapest near-term option for adding large scale, grid-connected generating capacity. But such investments run the risk of locking in decades of high carbon emissions and unless modern pollution controls are included- substantial quantities of conventional air pollutant emissions. These economy/environment trade-offs are difficult to navigate, especially for poorer countries with urgent near-term needs for low cost power. In those instances, assistance from developed countries to offset the additional costs and technology demands of more expensive but cleaner and lower-carbon technologies will be essential.

Nearer-term, commercialized alternatives to high emitting conventional coal plants include, among renewable technologies, primarily wind and biomass; higher-efficiency conventional coal plants (e.g., supercritical and fluidized bed systems); nuclear power; and where natural gas is available integrated combined-cycle gas turbines. Longer-term, advanced coal technologies such as integrated, combined-cycle gasification systems coupled with carbon capture and sequestration must be successfully commercialized to make continued reliance on coal resources compatible with global carbon constraints.

Of the major non-renewable, low-carbon generating options, modern natural gas systems are relatively clean and efficient and can be cost-competitive where ample supplies of natural gas are available. They can also be deployed relatively quickly and in small $(<100 \mathrm{MW})$ increments. Nuclear technology, by contrast, is far more demanding. China and India are poised to make substantial commitments to nuclear power in the next few decades. But for smaller developing countries this technology because of the operational and waste management challenges it presents, and its high upfront capital costs is unlikely to be attractive in the near- to mid-term. Advanced coal systems with carbon capture and sequestration are at an even earlier stage in the research, development and deployment trajectory. Given their high capital cost and the relatively unproved nature of the technology, most analysts believe that developed countries will need to take the lead in demonstrating and commercializing this option.

As noted in an earlier section, the mix of technologies and fuels used to meet electricity needs has become more diverse over time. In contrast, the transportation sector has remained with few exceptions overwhelmingly dependent on petroleum fuels. This is problematic both from an environmental standpoint (transportation accounts for roughly one-quarter of global energy-related carbon dioxide emissions) and an energy and economic security standpoint given recent trends in world oil markets. Rapid growth in vehicle ownership and overall travel are significant issues for many developing countries that are contending with already high levels of air pollution in urban centers and seeing a sharp rise in expenditures for imported oil.

In the near- to medium-term, developing and developed countries alike have two primary options for advancing sustainability objectives in the transportation sector: (1) improving vehicle performance through improved efficiency and emissions controls and (2) promoting sustainable, low-carbon biofuels as an alternative to petroleum-based fuels. Both options have drawn increased attention in recent years. A number of countries with large vehicle markets, including China and India, have adopted more stringent emissions standards and are considering automobile fuel-economy standards. At the same time, global interest in biofuels development has intensified markedly, in part because of the adoption of aggressive fuel mandates in developed countries like the United States. Brazil is already a world leader in this area, having successfully nurtured a major domestic sugarcane ethanol industry that is economically competitive with conventional gasoline.

The current worldwide boom in biofuels is proving a mixed blessing at best, however, especially in many developing countries where it is being blamed for contributing to accelerated rates of deforestation, habitat destruction and high food prices. These are significant issues and they should be addressed expeditiously through a thoughtful reexamination and reform of current biofuels policies not only in the developing world but also in the developed countries that are driving much of the recent push to expand global production.

In the long run, the viability of biofuels as an alternative to oil and the ability to manage or minimize tensions with food production and habitat preservation will depend on the successful commercialization of improved feed-stocks and conversion technologies. In general, such improvements an example would be the 
ability to cost-effectively convert ligno-cellulosic feed-stocks to ethanol would also greatly enhance the net environmental benefits and greenhouse gas reductions achieved by switching from conventional fuels to biofuels.

\subsection{Energy and economic growth}

The ability to control energy flows being a crucial factor for industrial production and socioeconomic development. Industrial societies are frequently characterized as 'high-energy civilizations'. Globally, per capita incomes are positively correlated with per capita energy use and economic growth can be identified as the most relevant factor behind increasing energy consumption in the last decades. Nevertheless, there is no agreement on the direction of the causal relationship between energy use and increased macroeconomic output, as the results crucially depend on the empirical methodology employed as well as the region and time period under study.

'Industrialization brings about structural change in the economy and therefore affects energy demand. As economic activity expands and diversifies, demands for more sophisticated and flexible energy sources arise: while societies that highly depend on agriculture derive a large part of primary energy consumption from traditional biomass coal and liquid fuels such as kerosene and liquid petroleum gas gain in importance with rising income, and electricity, gas and oil dominate at high per capita incomes. From a sectoral perspective, countries at an early stage of development consume the largest part of total primary energy in the residential and to a lesser extent agricultural sector. In emerging economies the manufacturing sector dominates, while in fully industrialized countries services and transport account for steadily increasing shares. Furthermore, several authors have pointed out that electricity which offers higher quality and greater flexibility compared to other forms of energy has been a driving force for the mechanization and automation of production in industrialized countries and a significant contributor to continued increases in productivity. Despite the fact that as a group industrialized countries consume significantly higher amounts of energy per capita than developing ones, a considerable cross-sectional variation of energy use patterns across countries prevails: while some countries (such as, e.g., Japan) display high levels of per capita incomes at comparably low levels of energy use, others are relatively poor despite extensive energy consumption, especially countries abundantly endowed with fossil fuel resources, in which energy is often heavily subsidized.

It is often asserted that developing and transition economies can 'leapfrog', that is, adopt modern, highly efficient energy technologies, to embark on less energy and carbon-intensive growth patterns compared to the now fully industrialized economies during their phase of industrialization. For instance, one study for twelve Eastern European member countries finds that between 1990 and 2000, convergence in per capita incomes (measured at purchasing power parity) between fully industrialized and transition economies has been accompanied by significant reductions of energy intensities in the latter. For industrialized countries, one hypothesis suggests that economic growth can largely be decoupled from energy use by steady declines in energy intensity as structural change and efficiency improvements trigger the 'dematerialization' of economic activity. However, despite the decreasing energy intensities (i.e., energy consumption per unit of GDP) observed over time in almost all regions, declines in energy intensity historically often have been outpaced by economic growth and hence have proved insufficient to achieve actual reductions in energy use . In addition, it has been argued that decreases in energy intensity in industrialized countries can partially be explained by the fact that energy-intensive industries are increasingly moved to developing countries

Despite fluctuations in global economic growth, some countries are consistent regional economic growth leaders. The dynamics and influence of these countries, particularly China, India, Brazil, and South Africa, will be critical in terms of shaping not only the developing world but global energy, economic, and climate change mitigation trends. The enormous investment needs in energy infrastructure by these countries in the coming decades will provide a unique window of opportunity for sustainable, low-carbon energy development. At the same time, they will continue to face the challenges of sustaining economic growth and eliminating poverty.

A proper understanding of the type and direction of causality between energy use and economic growth in developing countries would help illuminate the role of energy in the future evolution of these counties' economies. Soytas and Sari (2003) concluded that there is bi-directional causality in Argentina and causality running from GDP to energy use in Korea. Masih (1996) tested for co-integration between total energy use and real income of six Asian nations: India, Pakistan, Malaysia, Singapore, Indonesia, and the Philippines, and concluded the existence of unidirectional causality from energy to income for India, unidirectional causality from income to energy for Indonesia, and mutual causality for Pakistan. The pertinent inferences that were drawn by the authors from these conclusions were that improving living conditions and providing goods and services will require more energy services, and therefore an energy carrier is necessary. How much of this energy carrier is needed will depend on the energy end-use efficiency achieved in converting the energy carrier to energy services.

Another paper, based on data sets from 18 developing countries, refuted the neutrality hypothesis and concluded that energy use generally causes GDP growth and not vice versa (Lee, 2005 ). A recent paper focusing on China used a co-integration analysis and an error-correction model to examine the long-term equilibrium 
relationship between GDP and energy supply and use in 1980-2005 (Wang et al., 2008). It concluded that the two variables are co-integrated but specifically that the growth of GDP forcefully drives the growth of energy supply to increase while energy has a little effect on GDP. Based on this analysis, they concluded that if scientific actions were taken regarding development in the energy sector by: keeping a reasonable economic growth rate; optimizing industrial structures; exploring the use of high-efficiency energy utilization, and developing energy technology, then reducing the country's energy intensity by $20 \%$ in five years is achievable.

Despite not many publications being available on the causality between energy and economic development in Africa, Wolde-Rufael (2009) provided a good introduction to this issue and examined the relationship between energy use and economic growth for 17 African countries in a multivariate framework that included labor and capital as additional variables. He found the existence of causality between energy use and economic growth in 15 of the 17 countries. In Kenya and Zambia, energy relative to labor and capital was the most important determinant of economic growth, but causality running from energy use to economic growth was marginally rejected. In 11 countries, energy was not even the second most important factor when compared with capital and labor. Even though energy's contribution relative to output was not so high as that of capital or labor, its contribution to output growth was still relatively high in Algeria (29\%), Cameroon (41\%), South Africa $(23 \%)$, and Tunisia (44\%). Energy made the least contribution to economic growth in Coted'Ivoire, Gabon, Senegal, Sudan, and Zimbabwe (Wolde-Rufael, 2009).

An important observation is that for most African countries energy appears to be a smaller factor in economic growth and not as important as labor and capital. In contrast, for many industrialized and developing Asian economies energy is a relatively important contributing factor (Soytas and Sari, 2003; Soytas and Sari, 2006). This conclusion is consistent with the economic growth, energy supply, and use realities of most African countries. Many of these nations are characterized by low economic development, which is reflected in their limited energy development and consumption. In many cases energy supplies are unreliable and the infrastructure needed to meet the needs and demands are lacking. There is also the issue of consumers lacking access to commercial energy markets. All these characteristics of the energy sector tend to decouple energy supplies and use as drivers for economic growth and development. What is clear is that African countries must endeavor to find ways to direct investments into energy infrastructure development as well as to reduce inefficiencies in energy supplies and use in order to stimulate and promote sustainable economic development. In recent years, a number of African nations have become oil producers, boosting GDP and offering a source of funding for the development of energy infrastructure. Nevertheless, the proximity of oil production does not imply that more energy will get to African households and smaller businesses. Instead, coherent policies will be needed to ensure that the infrastructure and supply reach them.

Despite the many studies which estimate the effect of energy on economic development in developing economies, the research is fraught with difficulty. First, many low-income economies are predominantly agrarian. Much of their energy services are provided through muscular effort of human and animal power, which is not included in energy statistics. Similarly, a great deal of the heating, either for cooking or warming space and water, is fueled using biomass, which is also omitted from most estimates of energy use. Few econometric studies of the causality of energy on GDP (or for that matter, of GDP on energy) incorporate these traditional fuels. Also, time series studies in developing countries are based on few data points and cross-sectional analysis suffers from a great deal of economic, political, institutional, social, and cultural factors that are hard to include as variables. Thus, conclusions about the smaller influence of energy on GDP in developing economies compared with post-industrial ones must be taken with some caution (Chontanawat et al., 2008).

\subsubsection{Renewable Energy Consumption and Economic Growth}

The relationship between renewable energy consumption and economic growth can be classified under four testable hypotheses, namely; conservation, growth, feedback and neutrality. The conservation hypothesis requires a unidirectional causality flowing economic growth to energy consumption. This hypothesis implies that implementing energy conservation policies that curb energy consumption would not adversely affect economic growth. The growth hypothesis requires a unidirectional causality running from energy consumption to economic growth. This hypothesis posits that energy consumption contributes to economic growth. The feedback hypothesis requires bidirectional causality flowing between energy consumption and economic growth. This implies that energy consumption depends on economic growth and economic growth also depends on energy consumption. The neutrality hypothesis requires no causality flowing between energy consumption and economic growth. This implies that energy consumption has a small effect or no effect at all on economic growth. Many studies have been conducted on the causal relationship between economic growth and renewable energy consumption but have found mixed results (Apergis et.al 2016). Amri (2017) examined the relationship between economic growth and energy consumption under two categories- renewable and non-renewable energy consumption. The findings from the Autoregressive distributed lag (ARDL) model supported a long run relationship between economic growth and non-renewable energy consumption but no co-integration was found between renewable energy consumption and economic growth. The results posited bidirectional causality 
between non-renewable energy consumption and economic growth both in the short run and long run. Furthermore, the results revealed a unidirectional causality flowing from renewable energy consumption to economic growth in the long run.

Apergis et.al (2016) served to investigate the long run relationship between hydroelectricity consumption and economic growth for the 10 largest hydroelectricity consuming countries (Brazil, Canada, China, France, India, Japan, Norway, Sweden, Turkey and the USA). The study used annual data for the period 1965 to 2012. The results from the Bai and Perron (2003) tests of co-integration suggested an existence of a long run relationship between economic growth and hydroelectricity consumption. The results from a nonlinear panel smooth transition vector error correction model were divided based on the three structural breaks, 1988, 2000 and 2009. A one way causality from economic growth to hydroelectricity consumption was established in the long run and short for the period before 1988. For the period after 1988, a feedback hypothesis was realized between economic growth and hydroelectricity consumption in the long run and short run.

Omri, Mabrouk and Sassi-Tmar (2015) examined the causal link between energy consumption (nuclear energy and renewable energy) and economic growth for 17 developed and developing countries covering the period between 1991 and 2011. Mixed results were found for nuclear energy and renewable energy. Commencing with nuclear energy, their findings validated a one-way causality flowing from nuclear energy consumption to economic growth in Spain and Belgium, a unidirectional causality flowing from economic growth to nuclear energy consumption was established in Sweden, Netherlands, Canada and Bulgaria and bidirectional causality between nuclear energy and economic growth was found for Argentina, Brazil, France, Pakistan, and the USA. No causality was established for Finland, Hungary, India, Japan, Switzerland and the UK. The results for renewable energy and economic growth suggested a unidirectional causality from renewable energy consumption to economic growth in Hungary, India, Japan, Netherlands, and Sweden. A unidirectional causality from economic growth to renewable energy consumption was evident in Argentina, Spain and Switzerland whereas bidirectional causality was found for Belgium, Bulgaria, Canada, France, Pakistan and the USA. No causality was found for Brazil and realized for the panel while a conservation hypothesis was established between renewable energy consumption and economic growth.

The study by Halkos and Tzemes (2014) investigated the link between electricity consumption from renewable sources and economic growth for 36 countries covering the period between 1990 and 2011. The study used a non-parametric methodological technique. The study analyzed the entire sample of countries and then grouped the countries into sub-samples. The results for the entire sample of countries established that the relationship increases only up to a certain level of economic growth. A highly non-linear relationship was realized for emerging and developing countries while for developed countries, an increasing non-linear relationship was observed.

Sebri and Ben-Salha (2014) studied the relationship between economic growth, renewable energy consumption, carbon dioxide emissions and trade openness for the Brics countries. The study was taken over a period 1970 to 2010 using the ARDL bounds testing approach and the vector error correction model (VECM) technique. The results suggested an existence of a long run relationship between economic growth, renewable energy consumption, carbon dioxide emission and trade openness. The VECM model results supported bidirectional causality flowing between renewable energy consumption and economic growth.

Apergis and Payne (2014) investigated the relationship between renewable energy consumption, output, carbon dioxide emissions and fossil fuel prices for seven Central America countries for the period between 1980 and 2010. The results affirmed a long run relationship between renewable energy consumption, output, carbon dioxide emissions, coal prices and oil prices. The results further showed that these variables are positively and significantly related.

Ohlers and Fetters (2014) purposed to determine the causal linkage between electricity generated from different forms of renewables for the 20 Organization for Economic Co-operation and Development (OECD) countries covering the period between 1990 and 2008. Their findings from the Pedroni panel co-integration test confirmed that electricity generated from the renewables and economic growth has a long run relationship. Furthermore, they established a feedback hypothesis between economic growth and hydroelectricity in the short run.

Zirimba (2013) aimed to determine the relationship between economic growth and hydroelectricity consumption for Algeria, Egypt and South Africa for the period 1980 - 2009. The findings from the Toda and Yamamoto technique suggested a feedback link between hydroelectricity consumption and economic growth in Algeria. Moreover, it was established that economic growth Granger-causes hydroelectricity in South Africa while no causality was observed for Egypt.

Apergis and Payne (2012) investigated the linkage between renewable energy consumption, nonrenewable energy consumption and economic growth for 80 countries for the period $1990-2007$. The study employed the Pedroni heterogeneous panel co-integration test and panel error correction model. Their findings confirmed an existence of a long run relationship between economic growth, renewable energy consumption and non- 
renewable energy consumption, capital formation and labor. The results further supported a feedback link between renewable energy consumption and non-renewable energy consumption and economic growth in the long run and short run.

Apergis and Payne (2011) studied the link between renewable energy consumption and economic growth in six Central American countries covering the period from 1980 to 2016. The study employed the heterogeneous panel co-integration model and panel error correction model. Their findings confirmed an existence of cointegration between economic growth, renewable energy consumption, labor force and gross fixed capital formation. Furthermore, it was observed that there is a feedback relationship between renewable energy consumption and economic growth both in the long run and short run.

From the literature above, it can be realized that the ability to control energy flows being a crucial factor for industrial production and socioeconomic development. Industrial societies are frequently characterized as 'highenergy civilizations'. Globally, per capita incomes are positively correlated with per capita energy use and economic growth can be identified as the most relevant factor behind increasing energy consumption in the last decades. Nevertheless, there is no agreement on the direction of the causal relationship between energy use and increased macroeconomic output, as the results crucially depend on the empirical methodology employed as well as the region and time period under study.

\section{Conclusions}

One possible fear associated with a transition to a low carbon economy is the limits to economic growth that renewable energy sources might impose due to the availability of resources. After all, the standard narratives about the Industrial Revolution are that wood fuel could not have met the high energy demands associated with industrialization. That version of history is, no doubt, correct; but this review paper turns this argument on its head. It gathers evidence on past economies that managed within the confines of renewable energy systems. Focusing on wood fuels, it shows how in the Roman Empire, Early Modern Europe and the Far East renewable energy resources were the drivers of economic activity for very long periods. These were admittedly at slow growth rates by modern standards. But, they were also at times when technologies were very inefficient and transport networks poorly formed compared with the twenty-first century. For instance, with current technologies, transport infrastructures and institutional arrangements, the energy service demands of the Industrial Revolution would probably have been met quite easily with renewable energy sources.

This review paper does not argue that resources were always managed properly, or that resource limits did not hinder economic growth. Instead, it argues simply that renewable energy systems (have not and) will not be necessarily doomed to stagnation and collapse. Indeed, to be successful, economies (needed and) will need to balance their demands with their supplies and be 'sustainable'. But, if correctly managed, it may be possible to make a transition to a low carbon economy and grow within a renewable energy system for a very long time.

A great emphasis has been placed on a transition to a low carbon economy. This is appropriate given the threat of climate change, and the difficulties and uncertainties of a transition. However, less research has gone into investigating what happens once we reach a low carbon economy. The review paper begins this investigation by considering how economies in the past grew within the confines of a renewable energy system. It proposes two gaps in our knowledge. First, traditional models of long run energy use have not addressed the situation once the backstop technology, such as a renewable energy source, becomes the dominant energy source again. Although a transition to a low carbon economy is a long way off, if it ever occurs, it is now time to improve our understanding of the relationship between long run economic growth and renewable energy use. Second, we need to identify effective new policies that would be relevant for managing 'sustainably' (i.e. in the long run) 'sustainable' energy sources. This would need to develop incentives that would meet energy service demands within technically and commercially viable renewable energy supply limits that will be distributed effectively. Careful investigation of renewable energy systems may be crucial to determining whether a transition to a low carbon economy becomes a new golden age in economic history or another dark age.

\section{References}

1. Allen, R.C., Was there a timber crisis in Early Modern Europe in Cavaciocchi, S. (ed.) Economiae Energia, 2003,

2. Amri F, Intercourse across economic growth, trade and renewable energy consumption in developing and developed countries, Renewable and Sustainable Energy Reviews, 69 (2017) 527-534.

3. Apergis N. Chang T. Gupta R. and Ziramba E, "Hydroelectricity consumption and economic growth nexus: Evidence from a panel of ten largest hydroelectricity consumers, Renewable and Sustainable Energy Reviews, 62 (2016) 318-325.

4. Apergis N. and Payne J.E, Renewable and non-renewable energy consumption-growth nexus: Evidence from a panel error correction model, Energy Economics, 34(3) (2012) 733-738.

5. Apergis N. and Payne J.E, "The renewable energy consumption-growth nexus in Central America", 
Applied Energy, 88(1) (2011) 343 - 347.

6. Apergis N. and Payne J.E, "Renewable energy, output, $\mathrm{CO}_{2}$ emissions, and fossil fuel prices in Central America: evidence from a nonlinear panel smooth transition vector error correction model", Energy Economics, 42 (2014) 226-232.

7. Chontanawat, J., L. C. Hunt and R. Pierse, Does Energy Consumption Cause Economic Growth? : Evidence from a Systematic Study of over 100 Countries. Journal of Policy Modeling, 30 (2) (2008)209 220.

8. Cipolla, C.M, The Economic History of World Population, Pelican Books, London, 1962.

9. Fouquet, R., Heat Power and Light: Revolutions in Energy Services, 2008.

10. Fouquet, R., 'The Slow Search for Solutions: Lessons from Khobai H. and Le Roux P, 2017: "The relationship between energy consumption, economic growth and carbon dioxide emissions, The case of South Africa", International Journal of Energy Economics and Policy, 7(3), (2010b) 102-109.

11. $\mathbf{G}_{\mathbf{8}}$ Renewable Energy Task Force, Final Report, July 2001.

12. Lee, C.-C., Energy Consumption and GDP in Developing Countries: A Co-integrated Panel Analysis. Energy Economics, 27 (3) (2005) 415 - 427.

13. Jose Goldemberg (ed.), United Nations Development Program: World Energy Assessment: Energy and the Challenge of Sustainable Development, New York, 2000.

14. Masih, A. M. M. and R. Masih, Energy Consumption, Real Income and Temporal Causality: Results from a Multi-Country Study Based on Co-integration and Error-Correction Modelling Techniques. Energy Economics, 18 (3) (1996) 165 - 183.

15. Menyah K. and Wolde-Rufael Y, Energy consumption, pollutant emissions and economic growth in South Africa, The Journal of Energy Economics, 32 (2010) 1374-1382.

16. Okafor H.O, Testing the relationship between energy consumption and economic growth: Evidence for Nigeria and South Africa, Journal of Economics and sustainable development, 3(11) (2012) 111-124.

17. Nordhaus, W.D., Oil and economic performance in industrial countries, 1980

18. Rosenberg, N., The role of electricity in industrial development, The Energy Journal, 1998

19. Odhiambo N.M., Energy consumption, prices and economic growth in three SSA countries: A comparative study, Journal of Energy Policy, 38 (2010) 2463-2469.

20. Ohler A. and Fetters I, The causal relationship between renewable electricity generation and GDP growth: A study of energy sources, Energy economics, 43 (2014) 125-139.

21. Omri A., Mabrouk N.B., and Sassi-Tmar A, Modeling the causal linkages between nuclear energy, renewable energy and economic growth in developed and developing countries, Renewable and Sustainable Energy Reviews, 42 (2015) 1012-1022.

22. Sebri M. and Ben-Salha O, On the causal dynamics between economic growth, renewable energy consumption, $\mathrm{CO}_{2}$ emissions and trade openness: fresh evidence from BRICS, Countries, Renewable and Sustainable Energy Reviews, 39 (2014) 14-23.

23. Soytas, U. and R. Sari, Energy Consumption and GDP: Causality Relationship in G-7 Countries and Emerging Markets, Energy Economics, 25 (1) \{2003) 33 - 37.

24. Soytas, U. and R. Sari, Energy Consumption and Income in G-7 Countries, Journal of Policy Modeling, 28 (7) (2006) $739-750$.

25. Tahvonen, O., Salo, S., Economic growth and transitions between renewable and nonrenewable energy resources, European Economic Review, 2001

26. United Nations Development Program: World Energy Assessment: Overview, 2004

27. Update, Jose Goldemberg and Thomas Johansson (eds.), New York, 2004.

28. Wang, Y., J. Guo and Y. Xi, Study on the Dynamic Relationship between Economic Growth and China Energy Based on Co-integration Analysis and Impulse Response Function, China Population, Resources and Environment, 18 (4) (2008) 56 - 61.

29. Wolde-Rufael, Y., Energy Consumption and Economic Growth: The Experience of African Countries Revisited, Energy Economics, 31 (2) (2009) 217 - 224.

30. Ziramba E, Hydroelectricity consumption and economic growth nexus: time series experience of three African countries, European Scientific Journal, ESJ, 9(1), 2013 